\title{
Variations in body composition of poultry
}

\author{
By E. T. Moran JR, Department of Animal and Poultry Science, University of \\ Guelph, Guelph, Ontario $N_{1} G_{2} W_{1}$, Canada
}

Fowl have a body composition that is dominated by moisture, protein and fat while carbohydrate, minerals and vitamins represent a small part. Protein, carbohydrate, minerals and vitamins are related one to the other within the aqueous framework of the whole carcass and their proportions vary little. However, most of the fat is compartmentalized within adipocytes and extensive change in its amount may occur by simply displacing cytoplasm which is largely water. Fat represents the greatest variable in the body composition of fowl. In poultry, body fat changes with age, sex, genetics and nutrition in a manner parallel to other animals. However, anatomical and physiological idiosyncrasies that exist to accommodate egg formation have a direct bearing on lipid metabolism and the extent of variation of associated reserves. The present paper will briefly describe the main factors concerned with changes in body fat, then examine these idiosyncrasies and speculate on their mechanism of influence.

\section{Age and sex}

Once the yolk sac has dissipated, the composition of the body throughout juvenile development is consistently low in fat. The onset of sexual development leads to a rapid expansion of fat depots. Robbins \& Ballew (1984) recently examined the relation of sex and growth rate to the daily deposition of protein, fat and ash through the first 7 weeks of life with three strains of chickens. Protein and ash depositions were similar between strains but fat formed a greater part of early gain with fast-growing strains. Typically, females initiated body fat accrual earlier and to a greater extent than did males.

Females continue to have more body fat than do males through maturation to active reproduction. Thereafter, increase in body-weight is small and largely represented as a progressive expansion of body depots. The degree of this expansion varies. Meat-type chickens readily develop obesity and loss of reproductive activity follows unless some form of feed restriction is practised. Turkey hens represent an exception because nesting instincts facilitate a voluntary withdrawal from food shortly after peak egg production and depots become depleted.

Although insulin is instrumental in the formation of fat, other hormones dictate the terms of accrual. Absence of depot expansion before the initiation of sexual development can be attributed to growth hormone. The bulk of lipogenesis in fowl is restricted to the liver. Harvey et al. (1977) reported that growth hormone added to cultured hepatocytes not only abolished the stimulatory effect of insulin but 
encouraged lipolysis with adipose explants. The concentration of growth hormone is high after hatching, then declines to a basal level concurrent with sexual maturity (Scanes et al. 1984). Stewart \& Washburn (1983) observed that fast-growing broilers and females reduced their growth hormone levels earlier than did slow-growing birds and males, while lipogenic enzyme activities were unaltered. Sex hormones do not appear to regulate growth hormone since castration does not alter its circulating level with age (Scanes \& Johnson, 1984).

Sex steroids appearing with maturation are highly influential on the extent of fat deposition and the differentiation that develops between males and females. Oestradiol-i $7 \beta$ is particularly effective in expanding fatty acid synthesis, lipoprotein formation and release by the hepatocyte (Coleman et al. 1977; Dashti et al. 1983). Testosterone has been shown to oppose oestrogen in the hen (Pearce, 1977) and minimize fat accretion in cockerels (Snapir et al. 1983). Part of the effect of testosterone in reducing fat is through an enhanced muscular development, particularly through the pelvic and thigh areas (Ono et al. 1982, 1983).

\section{Depot fat locations}

Extensive collections of adipocytes occur in the skin and through the abdominal and pelvic areas. Subjective grading for skin fat is frequently done on dressed carcasses to estimate bird maturity and quality during meat inspection. Developing birds, especially females, have increased proportions of skin, offal and commercial cuts associated with the lower back (Ryley et al. 1970; Tzeng \& Becker, I981; Grey et al. 1982; Chambers \& Fortin, 1984).

The extent to which females develop their abdominal and pelvic depots is much larger than occurs with males. Moran ( 1984 ) noted that the edible portion from cooked chicken thighs contained more fat with females than males, even though both sexes were graded as equivalent in skin fat. Based on the triglyceride:DNA value, adipocytes in females are larger than those in males (Langslow \& Lewis, 1974).

Internal fat depots are particularly important to hens actively forming eggs. Yolk lipoprotein formation is a continual hepatic process. Reduced blood and nutrient movement from the intestine at night is envisaged to be compensated for by blood provided by the coccygeomesenteric vein carrying albumin-bound free fatty acids released from the abdominal and pelvic depots (Moran, 1982a). In this manner, all lobules in the liver are kept operational and vascular-parenchyma exchanges continue.

Free fatty acid release in response to glucagon is known to be acute in fowl. These fatty acids not only serve to perpetuate yolk lipoprotein formation in the egg-laying female but also act as an alternative energy source. The extent to which fatty acids are used for energy in the absence of food seems to differ between the sexes. Robbins et al. ( 1984 ) investigated the effect of continuous and $16 \mathrm{~h}$ light-8 $\mathrm{h}$ dark daily lighting on growth and body fat of broiler chickens. Both sexes reduced their rate of gain with interrupted lighting. Males had a similar relative amount of body fat after both regimens; however, body fat in females was lower following 
intermittent compared with continuous light, particularly on initiation of sexual development. Presumably, females give up additional fatty acids from their large depots and are less likely to resort to gluconeogenesis than are males.

\section{Dietary energy-protein balance}

In his review on the nutritional factors which affect body fat in fowl, McLeod (1983) concluded that the ratio, dietary energy:protein was the most influential. Having energy high relative to protein necessitates storage of the excess as fat. Conversely, high protein discourages fat deposition.

Relatively small changes in body-weight occur with deviation of the energy:protein value from optimal; however, alteration in body fat can be extensive. Ehinger \& Seemann (1982) gave combinations of practical extremes in dietary energy and protein to four strains of broiler chickens. Growth was similar between treatments while fat varied between 17 and $22 \%$ of the control carcass. All strains responded in the same manner and females had $2.5 \%$ more fat than males. In a similar experiment, Pesti \& Fletcher (1983) studied the effects of protein, energy and age on growth in one strain of male broilers and noted that carcass fat accounted for $19 \%$ of the variation.

\section{Dietary metabolizable energy $(M E)$ and added fat}

Adding fat to commercial poultry feed is normal, particularly for intensive production. This addition has been shown usually to increase the ME of the whole diet beyond that expected from the contribution of fat. On occasion the increase exceeds the gross energy from the fat itself (Scheibel et al. 1979). These 'extra energy' advantages are proportionately the greatest when the fat additions are low,

Table I. Effect of supplemental fat level on the gastrointestinal transit time of feed through hens and the feed metabolizable energy $(M E)$ content

(All diets were based on sunflower meal, soya-bean meal and maize. Yellow grease displaced ingredients such that amino acid balance and energy:protein were similar. Mean values with their standard errors are given for five hens that had been adapted to the respective diets for $7 \mathrm{~d}$ before experimentation. From Mateos \& Sell (1981) and Mateos et al. (1982))

\begin{tabular}{|c|c|c|c|c|c|c|c|c|}
\hline \multirow{2}{*}{$\begin{array}{c}\text { Supple- } \\
\text { mental } \\
\text { fat } \\
(\mathrm{g} / \mathrm{kg})\end{array}$} & \multicolumn{2}{|c|}{$\begin{array}{c}\text { First appearance } \\
\text { of chromic oxide } \\
\text { marker (min) }\end{array}$} & \multicolumn{2}{|c|}{$\begin{array}{l}\text { Apparent lipid } \\
\text { digestibility }(\%)\end{array}$} & \multirow{2}{*}{$\begin{array}{c}\text { Calculated } \\
\mathrm{ME}^{\star} \\
(\mathrm{MJ} / \mathrm{kg})\end{array}$} & \multicolumn{2}{|c|}{$\begin{array}{l}\text { Determined } \\
\mathrm{ME}(\mathrm{MJ} / \mathrm{kg})\end{array}$} & \multirow{2}{*}{$\begin{array}{c}\mathrm{ME}(\% \\
\text { of that } \\
\text { calcu- } \\
\text { lated })\end{array}$} \\
\hline & Mean & SE & Mean & $\mathrm{SE}$ & & Mean & SE & \\
\hline 0 & 193 & I 5 & $77 \cdot 3$ & 43 & 10.88 & 10.91 & 0.50 & 100 \\
\hline $5^{\circ}$ & 219 & 15 & $88 \cdot 0$ & I. I & II 60 & I I 74 & 0.10 & 101 \\
\hline 100 & 214 & 19 & $88 \cdot 1$ & $1 \cdot 4$ & $12 \cdot 32$ & $12 \cdot 73$ & 0.15 & 103 \\
\hline 150 & 227 & I I & $87 \cdot 6$ & $2 \cdot 6$ & 13.02 & 13.50 & 0.12 & 104 \\
\hline 200 & 251 & I6 & $89 \cdot 7$ & 4.0 & 13.74 & $14 \cdot 76$ & 0.20 & 107 \\
\hline $25^{\circ}$ & $25^{\circ}$ & 7 & $87 \cdot 1$ & $4 \cdot 3$ & 14.46 & 15.06 & 0.10 & 104 \\
\hline 300 & 270 & 17 & $90 \cdot 7$ & $1 \cdot 5$ & $15 \cdot 18$ & 15.96 & 0.10 & 105 \\
\hline
\end{tabular}

-Based on additivity of the ME values for the constituent feedstuff. 
and benefit to overall performance is best perceived when dietary protein is high relative to energy (Jensen et al. 1970).

Mateos \& Sell (198I) and Mateos et al. (1982) observed that increasing the level of added fat led to a progressive delay in the appearance of feed marker in the excreta while actual ME increased beyond that expected from the ingredients (Table I). They suggested that the delay improved digestibility of the ingredients other than fat.

Delay of digesta transit time can be rationalized in terms of fat absorption. Enterocytes convert the products of fat digestion into lipoproteins for release into the circulation. Apoprotein and lipoprotein synthesis appears to be the limiting factor in the overall process (Friedman \& Cardell, 1977). Once the absorptive capacity of the gut is exceeded, neural and hormonal mechanisms inhibit gastric evacuation while the nature of motility changes to reduce the distal progression of existing digesta (Moran, 1982a).

Fowl form very-low-density lipoproteins (VLDL) rather than chylomicrons (Sklan et al. 1984). VLDL have additional protein and phospholipid; thus, absorptive capacity is easily attained and delays in digesta transit time would be extended. Duke \& Evanson (1972) injected maize oil into the duodenum of turkeys and examined its effect on gizzard motility. Although the latent period until gastric inhibition was similar to mammalian response, the time necessary for recovery was noticeably longer.

Digesta transit time with fowl is very short compared with mammals. Values in Table I show that feed without added fat passes through the hen in $3.22 \mathrm{~h}$ while $50 \mathrm{~g}$ added fat $/ \mathrm{kg}$ increases this time by $14 \%$. Rapidly-growing broiler chickens have transit times half that for the hen and delays from fat may be very meaningful to the effectiveness of digestion. With its dependence on the duration of delay and feedstuff digestibility, the extent of the 'extra energy' effect is expected to be variable. Similarly, impact on body fat content will be inconsistent, relating to those nutrients benefiting from the delay, existent protein:energy, and age and sex of the bird.

\section{Fatty acid composition}

Mammals transfer chylomicrons from the intestine by lymph vessels to the superior vena cava where they have direct access to peripheral tissues. The lymphatic system is poorly developed in fowl; however, the VLDL are small and enter the portal system. Particulates in blood passing through the liver are prevented from direct access to the hepatocytes if they are larger than the fenestrations lining the lobule sinusoid. Saturated dietary fat has been shown to result in smaller chylomicrons from rat intestine than when unsaturated fat is fed (Boquillon $e t$ al. 1977). A parallel situation in fowl would effect a differential access by VLDL to hepatocytes and permit selective modifications in fatty acid composition.

Marion \& Woodroof ( $\mathrm{g} 966$ ) offered broiler chickens feed with $50 \mathrm{~g}$ added fat $/ \mathrm{kg}$ from diverse sources. Little stearic acid could be found in the carcass when beef tallow was fed; however, linoleic acid readily appeared in response to safflower oil 
Table 2. Effect of saturated and unsaturated dietary fat supplements on the fatty acid composition of chicken broilers

(Maize-soya-bean-meal feed containing the respective sources of added fat were given from hatching to $5^{8} \mathrm{~d}$ of age. Analyses were done on chloroform extracts of dressed ready-to-cook carcasses. Mean values are from twelve males and expressed as \% total fatty acids. From Marion \& Woodroof (1966))

\begin{tabular}{|c|c|c|c|c|c|c|}
\hline \multirow[b]{2}{*}{ Fatty acid } & \multicolumn{2}{|c|}{ No added fat } & \multicolumn{2}{|c|}{$5 \circ \mathrm{g}$ Beef tallow $/ \mathrm{kg}$} & \multicolumn{2}{|c|}{$50 \mathrm{~g}$ Safflower oil $/ \mathrm{kg}$} \\
\hline & Diet & Carcass & Diet & Carcass & Diet & Carcass \\
\hline $12: 0$ & - & 0.2 & 0.7 & 0.2 & - & 0.2 \\
\hline $14: 0$ & 0.1 & 0.8 & 3.0 & 2.4 & 0.2 & 0.5 \\
\hline $14: 1$ & - & 0.3 & 0.7 & $1 \cdot 2$ & - & - \\
\hline $16: 0$ & $13 \cdot 1$ & 25.7 & $22 \cdot \mathrm{I}$ & $25 \cdot 3$ & II. 4 & 14.4 \\
\hline $16: 1$ & 0.5 & 7.4 & 1.8 & 5.8 & 0.2 & $2 \cdot 2$ \\
\hline $18: 0$ & 2.5 & $6 \cdot 2$ & 19.7 & 8.8 & 1.8 & 4.5 \\
\hline $18: 1$ & 310 & 38.6 & 30.5 & $38 \cdot 2$ & 18.8 & 20.6 \\
\hline I $8: 2$ & $51 \cdot 3$ & $20 \cdot 1$ & 18.9 & I6. 5 & $67 \cdot 2$ & $56 \cdot 6$ \\
\hline $18: 3$ & 1.6 & 0.6 & $I \cdot 5$ & I. 5 & 0.4 & 0.9 \\
\hline
\end{tabular}

(Table 2). Fowl hepatocytes are adept at converting stearic to oleic acid (Holloway \& Holloway, 1974; Jeffcoat \& James, 1978). Presumably, 'large' VLDL were formed from safflower oil and hepatocyte exclusion led to direct deposition and protection of the essential fatty acids for possible recall. After studying the influence of dietary fat on the incorporation of fatty acids into body and egg fat, Feigenbaum \& Fisher (1959) suggested that any dietary polyenoic inadequacies in the hen for egg formation are compensated for by selective withdrawal from depots.

Coping with extremes in dietary fatty acid composition requires energy. Saturated fats are desaturated only after VLDL disassembly, then another VLDL must be reassembled for transport out of the hepatocyte. Synthesis of saturated fatty acids from carbohydrate appears to be the method by which extremes in unsaturated fats are moderated (Marion \& Woodroof, 1966). Fuller \& Rendon (1977, 1979) examined the efficiency of various sources of fat for chick growth. Poultry fat consistently had the best productive energy and the lowest associated heat increment.

\section{Growth response to fat}

Fat is added to feed for high-performance fowl because this usually produces an increased rate of growth. This benefit is separate from the 'extra energy' effect and the productive energy advantage obtained by avoiding the heat increment of fat synthesis. Lipids form a part of growth as membranes and depots. Fatty acid synthesis is centralized in the liver and when rapid growth occurs dietary fat appears to relieve a finite hepatocyte population of the burden. Indirect support for this limitation is provided by the inability of large insulin doses to cause severe hypoglycaemia in fowl. 
Genetic selection for growth at a time when hepatic lipogenesis is one of the limiting factors leads to progeny having increased body fat. Hood (1984) selected broiler chickens over eight generations for weight gain, feed consumption capacity or feed conversion efficiency. Final body-weight was greatest when gain was the object of selection and lowest with feed conversion efficiency. Body fat and hepatic lipogenic capacity were maximized when feed consumption was the focus of attention and minimal for feed conversion efficiency. Body fat was found to be correlated with plasma VLDL concentration; however, hepatic malate dehydrogenase ( $E C$ I.1.1.40) and ATP citrate lyase ( $E C$ 4.1.3.8) were not.

Growth response to fat diminishes as its dietary level increases. Owen et al. (1981) noted that male turkeys showed no further improvement in rate of gain beyond $40 \mathrm{~g}$ added fat $/ \mathrm{kg}$ in maize-soya-bean-meal rations; however, Owings \& Sell (1982) found female turkeys to benefit from up to $80 \mathrm{~g}$ added fat $/ \mathrm{kg}$ under similar dietary circumstances. Differences in the maximum level for response probably relates to the proportion of growth devoted to fat and the amount needed from the feed to offset the limitation in de novo synthesis.

The nature of the growth response appears to differ when unsaturated or saturated fats are given. Grimbergen et al. (1982) substituted soya-bean oil for carbohydrate in a manner that maintained the ME level of the feed. Broiler chickens were given the two treatments between 5 and 7 weeks of age. A significant improvement in growth rate, and ME and protein utilization occurred but no alteration in body fat could be detected (Table 3 ). Moran (1982b) gave turkeys, between 18 and 22 weeks of age, feeds with and without added tallow where the energy:protein value was maintained (Table 4). Half-way through this final phase of production at 20 weeks, a significant increase in body-weight occurred in response to added fat although this same effect was not seen 2 weeks

Table 3. Improved growth by isoenergetic substitution of soya-bean oil for carbohydrate in feed with broiler chickens between 5 and 7 weeks of age

(A semi-purified diet was used that contained soya-bean-meal, fish meal, maize, starch and sucrose. Soya-bean oil displaced an equivalent amount of metabolizable energy (ME) as starch-sucrose. From Grimbergen et al. (1982))

\begin{tabular}{|c|c|c|}
\hline & \multicolumn{2}{|c|}{$\begin{array}{l}\text { Added soya-bean oil } \\
\qquad(\mathrm{g} / \mathrm{kg})\end{array}$} \\
\hline & 0 & 60 \\
\hline Gain $5-7$ weeks $(\mathrm{g})$ & $5^{13}$ & $538^{\star \bullet}$ \\
\hline Protein in carcass at 7 weeks (\%) & $19 \cdot 2$ & $19 \cdot 2$ \\
\hline Fat in carcass at 7 weeks $(\%)$ & 15.0 & $15 \cdot 2$ \\
\hline ME consumed $\left(\mathrm{kJ} / \mathrm{kg}\right.$ body-weight $(\mathrm{W})^{0.75}$ per $\left.\mathrm{d}\right)$ & 1155 & $1134^{\circ \bullet}$ \\
\hline $\mathrm{ME}$ retained $\left(\mathrm{kJ} / \mathrm{kg} \mathrm{W^{0.75 }}\right.$ per d) & 354 & $368^{* *}$ \\
\hline Fat formed (g/kg Wor $W^{015}$ per & $5 \cdot 5^{8}$ & $5 \cdot 78^{\bullet}$ \\
\hline Protein consumed (g/kg W" $\mathrm{K}^{0.75}$ per $\left.\mathrm{d}\right)$ & 13.4 & $13 \cdot 3$ \\
\hline Protein formed ( $\left(\mathrm{g} / \mathrm{kg} \mathrm{W}^{0.75}\right.$ per $\left.\mathrm{d}\right)$ & $5 \cdot 88$ & $6 \cdot 15$ \\
\hline
\end{tabular}

Significantly different: ${ }^{\bullet P} P<0 \cdot 01$. 
Table 4. Effect of added tallow to feed, while maintaining the energy:protein value, on performance of early- and late-marketed turkeys

(Feed was based on maize and soya-bean-meal. Large-type turkeys were used and experimentation was initiated at 18 weeks of age when body-weight averaged $10556 \mathrm{~g}$. The subjective grade for skin fat is highly correlated with its fat content. From Moran (1982a,b))

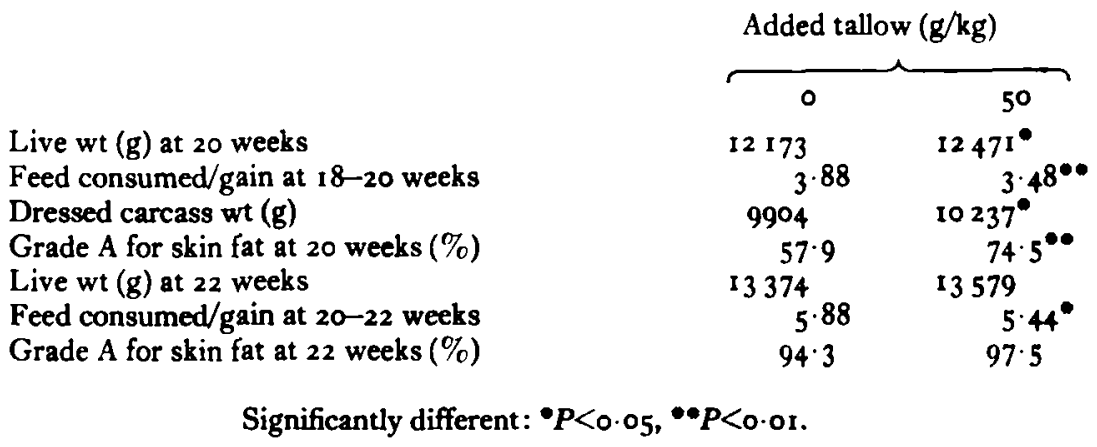

later. Similarly, subjective grading for fat in the skin with early marketing indicated that more extensive depots were present when tallow was given; again this difference could not be detected 2 weeks later.

Differences in the nature of this growth response can be rationalized if fowl use the fat given to best advantage. Presumably, unsaturated fatty acids are appropriate for membrane expansion and would also facilitate protein accrual while saturated fatty acids have value as reserve energy in depots.

\section{Overview}

Poultry have a body composition that changes with development, differs between the sexes and responds to nutrition. Like other animals, depot fat is the greatest variable; however, a particularly wide range is possible because of idiosyncrasies relating to lipid metabolism and the accommodation of egg-yolk formation.

The liver is the focal point of lipid metabolism in fowl. Dietary fat is converted to VLDL during absorption and these are directly transferred to the liver where constituent fatty acids may be modified before yolk or peripheral tissue deposition. Adipocytes are sensitive to glucagon and resultant free fatty acids in major depot areas may be directly returned to the liver through a unique vein; thus, yolk formation will continue when food is absent. For the most part, fatty acid synthesis is also confined to the liver where a finite number of hepatocytes appear to limit performance when fat must be formed in large quantities.

Variation in the amount of body fat is expected to be the greatest at the initiation of sexual maturity when lean and fat depot growth are extensive. Dietary circumstances exaggerate variation at this time. The presence of fat generally increases feed digestibility because of delays from VLDL formation, and also facilitates growth by avoiding the constraints of de novo synthesis. The absence of 
dietary fat has the opposite effect. Females are expected to vary more than males because their depots are large and hormonal differences permit greater responses. Centralization of lipid metabolism also influences fatty acid composition of egg and tissues; however, variation in this respect is reduced as a result.

\section{REFERENCES}

Boquillon, M., Paris, R. \& Clement, J. (1977). Lipids 12, 500-504.

Chambers, J. R. \& Fortin, A. (1984). Poultry Science 63, 2187-2196.

Coleman, R., Polokoff, M. A. \& Bell, R. M. (I977). Metabolism 26, 1123-I I 30 .

Dashti, N., Kelley, J. L., Thayer, R. H. \& Ontke, J. A. (1983). Fournal of Lipid Research 24, $368-380$.

Duke, G. E. \& Evanson, O. A. (1972). Poultry Science 51, 1625-1636.

Ehinger, F. \& Seemann, G. (1982). Archiv für Geflugelkunde 46, 177-188.

Feigenbaum, A. S. \& Fisher, H. (1959). Archives of Biochemistry and Biophysics 79, 302-306.

Friedman, H. I. \& Cardell, R. R. (1977). Anatomical Record 188, 77-102.

Fuller, H. L. \& Rendon, M. (1977). Poultry Science 56, 549-557.

Fuller, H. L. \& Rendon, M. (1979). Poultry Science 58, $1234-1238$.

Grey, T. C., Robinson, D. \& Jones, J. M. (1982). British Poultry Science 23, 289-298.

Grimbergen, A. H. M., Stappers, H. P. \& Cornelissen, J. P. (1982). Netherlands fournal of Agricultural Science 30, $115^{-125}$.

Harvey, S., Scanes, C. G. \& Howe, T. (1977). General and Comparative Endocrinology 33, $322-328$.

Holloway, C. T. \& Holloway, P. W. (1974). Lipids 9, 196-200.

Hood, R. L. (1984). World's Poultry Science Association fournal 40, 160-169.

Jeffcoat, R. \& James, A. T. (1978). FEBS Letters 85, 1 14-1 18.

Jensen, L. S., Schumaier, G. W. \& Latshaw, J. D. (1970). Poultry Science 49, 1697-1 704.

Langslow, D. R. \& Lewis, R. J. (1974). British Poultry Science 15, 267-273.

McLeod, J. A. (1983). World's Poultry Science Association fournal 39, 194-200.

Marion, J. E. \& Woodroof, J. G. (1966). Poultry Science 45, $241-247$.

Mateos, G. G. \& Sell, J. L. (198I). Poultry Science 60, $1509-1515$.

Mateos, G. G., Sell, J. L. \& Eastwood, J. A. (1982). Poultry Science 6r, 94-100.

Moran, E. T. (1982a). Comparative Nutrition of Fowl and Swine: The Gastrointestinal Systems. Guelph: Office for Educational Practice, University of Guelph.

Moran, E. T. (1982b). Poultry Science 61, 919-924.

Moran, E. T. (1984). In Proceedings of the Monsanto Canada Technical Symposium, Toronto, pp. $123-133$.

Ono, Y., Iwamoto, H. \& Takahara, H. (1982). Scientific Bulletin of the Faculty of Agriculture, Kyushu University 37, 23-30.

Ono, Y., Iwamoto, H. \& Takahara, H. (1983). Japanese Fournal of Zootechnical Science 54, 453-459.

Owen, J. A., Waldroup, P. W., Mabray, C. J. \& Slagter, P. J. (1981). Poultry Science 60, 418-424.

Owings, W. J. \& Sell, J. L. (1982). Poultry Science 61, 1897-1904.

Pearce, J. (1977). Fournal of Endocrinology 75, 343-344.

Pesti, G. M. \& Fletcher, D. L. (1983). British Poultry Science 24, $91-99$.

Robbins, K. R., Adekunmisi, A. A. \& Shiriey, H. V. (1984). Growth 48, 269-277.

Robbins, K. R. \& Ballew, J. E. (1984). Growth 48, 44-58.

Ryley, J. W., Moir, K. W., Pepper, P. M. \& Burton, H. W. (1970). British Poultry Science II, 83-91.

Scanes, C. G., Harvey, S., Marsh, J. A. \& King, D. B. (1984). Poultry Science 63, 2062-2074.

Scanes, C. G. \& Johnson, A. L. (1984). General and Comparative Endocrinology 53, 398-40r.

Scheibel, M. S., Coon, C. N. \& Kelley, K. W. (1979). Nutrition Reports International 20, 871-88I. 
Sklan, D., Geva, A., Budowski, P. \& Hurwitz, S. (1984). Comparative Biochemistry and Physiology 78A, 507-510.

Snapir, N., Robinzon, B. \& Shalita, B. (1983). Pharmacology, Biochemistry and Behaviour 19, $617-624$.

Stewart, P. A. \& Washburn, K. W. (1983). Growth 47, 411-425.

Tzeng, R.-Y. \& Becker, W. A. (1981). Poultry Science 60, 1 10I-1 106. 